\title{
PERSPECTIVES ABOUT THE EXECUTION OF POLICE POWERS AND FUNCTIONS IN THE REPUBLIC OF ZIMBABWE
}

ISHMAEL MUGARI ${ }^{1}-$ EMEKA E. OBIOHA ${ }^{2}$

\begin{abstract}
This study was conducted to explore views about the execution of powers and functions of the police in the light of related challenges. This study made use of data from a total of 83 adult participants (a survey involving 73 individuals, and 10 in-depth interviews), including males and females of diverse occupational backgrounds from Bindura and Mount Darwin policing districts in Zimbabwe. A closed-ended, mostly Likert-scale-based questionnaire was used to collect data about the prevalent forms of police abuse of powers and functions, while an indepth interview guide was provided to harvest information qualitatively. Findings reveal that police officers abuse their powers through unlawful arrests, arbitrary search and seizure, excessive use of force, unlawful methods of investigation, and ill treatment of detainees. Though not as prevalent as other forms of abuse, malicious criminal prosecution and partisan policing were also cited.
\end{abstract}

KEYWORDS: powers, abuse, function, police, Zimbabwe

\section{INTRODUCTION}

Police officers play an important role in societies and their presence promotes a sense of security among citizens. The public look up to the police to guarantee their safety and, importantly, to protect their fundamental human rights. To enable them to carry out their mandate, police officers are given wide discretionary

\footnotetext{
1 Ishmael Mugari was a postgraduate candidate at the Department of Safety and Security Management, Tshwane University of Technology, Pretoria, South Africa. He is currently a lecturer at Bindura University of Science Education, Zimbabwe, e-mail: ishiemugari@gmail.com

2 Emeka E. Obioha (Corresponding Author) is a professor at the Department of Social Sciences, Walter Sisulu University, South Africa, e-mail:emekaobioha@gmail.com; eobioha@wsu.ac.za.
} 
powers, which should however be exercised within the confines of the law. Failure to follow due process during the exercise of police powers amounts to police abuse of power. Accordingly, the last thing that the public expects is for those who are empowered to protect them to be the violators of their rights. The Zimbabwe Republic Police has met with its fair share of success stories and challenges in this regard since its inception following independence in 1980.

The national Zimbabwe Republic Police (Z.R.P) is headquartered in Harare under the command of a commissioner general. The ZRP was formed at the time of independence in 1980 after the amalgamation of the colonial British South African Police (B.S.A.P) and two liberation movements, namely: the Zimbabwe African National Liberation Army (ZANLA) and the Zimbabwe People's Revolutionary Army (ZIPRA). The organization was established under Section 93 (1) of the then Lancaster House Constitution of 1980, which provided that: "There shall be a police force which, together with such other bodies as may be established by law for the purpose, shall have the function of preserving the internal security of and maintaining law and order in Zimbabwe." The current constitution, which came into effect in 2013, provides for the establishment of a police service. Section 219 of the Constitution of Zimbabwe Amendment (No 20) Act of 2013 [hereinafter referred to as the Constitution of Zimbabwe] provides that: "There is a Police Service which is responsible for- Detecting, investigating and preventing crime; Preserving the internal security of Zimbabwe; Protecting and securing the lives and property of the people; Maintaining law and order; and Upholding this Constitution and enforcing the law without fear or favour". Of note is the fact that the Lancaster House Constitution referred to the police organization as a police force, whereas the new constitution refers it as a police service. The term "force" had negative connotations, as it seemed to legitimize any kind of force (including excessive force), in the interests of performing the policing function.

Policing during the pre-independence era was mainly done within the purview of fighting terrorism. Ironically, however, perceived terrorists were often members of the former liberation movements ZANLA and ZIPRA. The Z.R.P inherited a police force that served a government which had used a state of emergency to evoke a wide range of extreme powers to try to suppress the struggle for majority rule (Feltoe 1997:19). The white minority government in the pre-independence era had created a network of draconian security laws; the most notorious of which were the Law and Order (Maintenance) Act [Chapter 9:15] of 1965 and The Emergency Powers Act [Chapter 11:04] of 1960. These laws remained in the country's statutes even after independence. The state of emergency was also prolonged until 1992. Commenting on the state of policing after independence, Feltoe (1997) writes that: 
"Many police officers that had known no other form of policing than under a state of emergency under which extreme and extraordinary powers could be used remained in various security forces. Many of the notorious torturers of the various intelligence units of the former remained in office; some became the trainers of the new regime or the trainers of tortures of the new regime" (p.20).

From Feltoe's perspective about the state of policing, it can be argued that the police culture that characterized the pre-independence era could have crept into the post-independence era. Though the Law and Order (Maintenance) Act was replaced by the Public Order and Security Act [Chapter 11.17], which is commonly referred to as POSA, the latter has also had its fair share of criticism. Some sections of POSA have been ruled unconstitutional for violating fundamental human rights. A specific provision, which has long been considered to be unconstitutional, is Section 27 of POSA, which accords the regulating authority (Officer Commanding Police District) the power to temporarily prohibit public demonstrations in the interests of national security. This section has faced criticism from a broad spectrum of civic society, as it is perceived to violate citizens' freedom of association. Despite being rendered unconstitutional, the section still remains in the act and the police enforce the statutory provision.

As a way of improving the strained relations between Z.R.P and the public, the organization launched a Service Charter in 1995. The Service Charter sets out the minimum policing standards that the public should expect from the police. It is based on the five core areas of policing, namely; Response to calls, Crime, Traffic, Public order and reassurance, and Community assistance. When police officers fail to act in accordance with the norms and values set out in the Service Charter, this represents malperformance on the part of the police. The Service Charter can be viewed as a great stride in transforming the Z.R.P from a feared police force to a progressive police service.

One of the tenets of the Service Charter is that it creates a platform for the public to complain against wrongful police action whenever police officers fail to match up to their own set of standards of policing. With the proliferation of various media houses - both private and public -, the media has become a mouthpiece for the public in its vilification of wrongful police action. Members of the public are also increasingly being educated about their rights by nongovernmental organizations (NGOs) through the use of various media platforms such as the Legal Forum (a weekly newsletter for human rights NGOs) that educate the public. With an increase in the awareness of their rights as guaranteed by the constitution, public citizens are no longer hesitating to sue the police whenever they suffer as a result of the police abuse of powers and function. 
Incidences of abuse of powers and functions have been reported by NGOs. Z.R.P has consistently arrested thousands of human rights defenders, yet there has not been one single conviction (Anti-Corruption Trust of Southern Africa, 2013:3). The absence of convictions in all these cases suggests that arbitrary arrests are being made by the police (Anti-Corruption Trust of Southern Africa, 2013:3). According to Human Rights Watch (2008:2), police detain accused persons beyond the forty-eight hour statutory limit, show contempt for court proceedings, and frequently deny detainees access to legal representation or relatives. In its report on policing in Zimbabwe, The International Bar Association on Human Rights Institute (2007) also highlighted that police routinely disregard the basic rights of detainees, such as allowing free access to lawyers, and access to family members, medical personnel and courts.

As a result of the indiscriminate use of powers, Z.R.P is also losing large sums of money due to successful civil suits against the police. In one prominent case (Karimazondo and Another vs. Minister of Home Affairs and Another 2001 (2) ZLR $363(H)$ ), the plaintiffs were awarded a total of Z\$1 500000 (US\$30 000) for a civil suit following allegations of unlawful arrest, assault and torture. Several other successful civil suits have been filed against the Z.R.P. For example, in Nyandoro vs. Minister of Home Affairs and Another (HH-196-2010), the plaintiff was awarded US\$5 000 after successfully suing the police for assault, while in Muskwe vs. Minister of Home Affairs and Others (HH-83-2013) a sixty-fiveyear-old plaintiff was awarded US\$1 500 after suing for unlawful arrest and detention. Moreover, lives are also being lost and unnecessary injuries are being inflicted on citizens as the police use excessive force when dealing with public disorder situations. Against this background, this study was carried out with the objective of documenting the prevalent forms of police abuse of powers and functions.

\section{BRIEFING ON ZRP POLICE STATUTORY POWERS}

The police function of maintaining law and order requires that some powers are bestowed on police officers. These powers of arrest, search and seizure are clearly outlined in the Criminal Procedure and Evidence Act [Chapter 9:07]. The grounds on which these powers may be exercised, as well as the limits of these powers, are also outlined in the Act. 


\section{Power of arrest/detention}

During investigations, police are accorded power to arrest those reasonably suspected or known to have committed crimes, or those who commit offences in their presence (Criminal Procedure and Evidence Act). The reasons for arrest and detention were clearly spelt out in the case of Botha vs. Zvada 1997 (1) ZLR 415 (S) in which a seventy-one-year-old man was arrested and detained for six days on suspicion of committing murder, as follows;

1. To prevent the accused from absconding from court

2. To stop the accused from committing further crimes

3. To stop the accused from interfering with investigations and witnesses.

In the circumstances, it was held that the arresting officer had no reasonable grounds for suspecting that the appellant had committed murder, and that the decision to arrest and hold the appellant in custody was unreasonable as there was no reason to believe that a seventy-one year old would escape. It therefore follows that when none of the above three principles (often known as 'The Wednesbury principles') are taken into account, arresting and detaining an individual constitutes a violation of rights.

\section{Police powers of search and seizure}

The Criminal Procedure and Evidence Act empowers police officers to search individuals and their property and to seize items suspected to have been involved in the commission of a crime. Searches, especially of individuals, their homes, other property and vehicles and the interception of correspondence, telephone messages or other communication must be strictly legal and legitimate for law enforcement purposes (Mudzongo 2002).

\section{RESEARCH METHODOLOGY}

\section{Participants}

Eighty-three participants (all members of the public; fifty-two male and thirty-one female) from two policing districts (Bindura, and Mount Darwin) were invited to take part in the study. Of the eighty-three, forty-two respondents 
were resident in Bindura, whilst thirty-five respondents were resident in Mount Darwin. The remaining six respondents worked in the two districts but lived outside them. Bindura is the provincial capital of Mashonaland Central Province, hence it is an urban policing area, whilst Mount Darwin is a rural district within the same province. Given the difference in the political and socio-economic environment between rural and urban areas in Zimbabwe, the researchers also intended to foster a comparison of perceptions between a rural community and an urban community.

Stratified random sampling, snowball sampling and purposive sampling techniques were used. Participants were selected due to the nature of their work and their perceived appreciation of the policing function, and they were mainly drawn from the following professions: lawyers, community leaders, academics, business actors, and human rights activists.

\section{Instruments}

A questionnaire with closed-ended questions was used to collect data from seventy-three respondents who were asked to respond about the prevalent forms of police abuse of powers and functions. Variables that were covered included unlawful arrests, arbitrary search and seizure, malicious criminal prosecution, and partisan policing. Respondents were asked to indicate whether the abuses were common in their areas by ticking one of the following options on a threeitem scale: 'not common', 'common' and 'very common'. Respondents were also asked about their perception of the treatment of persons detained by the police. Responses were indicated on a scale which ranged from 'strongly disagree' to 'strongly agree' in relation to variables such as access to medication, assault by police officers, and access to legal representation. However a major drawback of this study was that some respondents did not provide answers to particular questions, though such instances were not significant enough to negatively affect the overall outcome of the study. In-depth interviews were conducted with ten respondents, including lawyers, civic society players, and academics. Quantitative data which was obtained through questionnaires was coded and fed into The Statistical Package for the Social Sciences (SPSS Version 16) for analysis. Data obtained through in-depth interviews was used to compliment this quantitative data. 


\section{FINDINGS AND DISCUSSION}

\section{Unlawful arrest: Abuse of police power to arrest}

An unlawful arrest happens when police, without lawful justification, restrict the liberty of citizens during arrest and imprisonment (Feltoe 2012). A wrongful arrest may include an arrest of a person without probable cause, an arrest for the purpose of a police interview, and an arrest for the purpose of identification by police (Feltoe 2012).

An unlawful arrest is a violation of the right to personal liberty, and Section 49 of the constitution provides that every person has a right not to have their liberty deprived arbitrarily or without just cause. Similarly, Section 50 of the constitution provides for the rights of arrested and detainees, the major highlight being the specification of a maximum forty-eight hour period of detention after an arrest. Whilst there may not be a specific law that outlaws unlawful arrest in Zimbabwe, what the constitution and the Criminal Procedure and Evidence Act [Chapter 9:11] do is to provide guidelines that should be followed when carrying out an arrest.

The study revealed that unlawful arrest was considered by a majority of respondents to be a prevalent form of abuse (Table 1). A total of $72.6 \%$ of respondents considered unlawful arrest to be either very common (38.4\%) or common (34.2\%). Only 27.4 percent considered unlawful arrest to be uncommon.

Table 1 Respondents' perceptions about the prevalence of unlawful arrest

\begin{tabular}{ccc}
\hline Response & Frequency & Percent \\
Not common & 20 & 27.4 \\
Common & 25 & 34.2 \\
Very common & 28 & 38.4 \\
Total & 73 & 100.0 \\
\hline
\end{tabular}

Further analysis of the data by area of residence (Table 2) shows that unlawful arrests are prevalent in Bindura district, as reported by 37.8 percent of the respondents who considered unlawful arrest to be either common or very common. Slightly over a third (36.7 percent) of all respondents from Mt. Darwin district considered unlawful arrest not to be common, as compared to 24.3 percent who considered unlawful arrest not to be common in Bindura District. The above statistics can be explained by the fact that police actions are more visible in urban areas than in rural areas, and incidences of police abuse of power are likely to be more noticeable in urban areas. One explanation is that 
police actions - both good and bad - are more visible in urban areas which are densely populated, as compared to sparsely populated rural areas.

Table 2 Prevalence of unlawful arrest by area of residence (respondents' perceptions)

\begin{tabular}{ccccc}
\hline \multirow{2}{*}{ Residence } & \multicolumn{3}{c}{ Prevalence of unlawful arrest } & \multirow{2}{*}{ Total } \\
& Not common & Common & Very common & \\
\hline \multirow{2}{*}{ Bindura } & 9 & 14 & 14 & 37 \\
& $24.3 \%$ & $37.8 \%$ & $37.8 \%$ & $100.0 \%$ \\
\multirow{2}{*}{ Mt. Darwin } & 11 & 8 & 11 & 30 \\
& $36.7 \%$ & $26.7 \%$ & $36.7 \%$ & $100.0 \%$ \\
Other & 0 & 3 & 3 & 6 \\
& $.0 \%$ & $50.0 \%$ & $50.0 \%$ & $100.0 \%$ \\
\hline \multirow{2}{*}{ Total } & 20 & 25 & 28 & 73 \\
& $27.4 \%$ & $34.2 \%$ & $38.4 \%$ & $100.0 \%$ \\
\hline
\end{tabular}

Most of the members of the public who were interviewed concurred that police officers engage in unlawful arrests. Some of the interviewees highlighted the following forms of unlawful arrest:

- Being arrested on unjustifiable grounds, only to be released after a day or two in detention

- Not being informed of the offence at the time of arrest

- Detaining suspects in order to investigate them

One of the interview respondents from the legal profession stated that he had offered legal help to several clients who had been arrested without reasonable cause, with some not even aware of the charges against them. This also suggests arbitrary arrests by the police. An unlawful arrest violates a citizen's right to personal liberty. Various conventions and treaties have been signed to outlaw illegal arrests. The most notable are The International Covenant on Civil and Political Rights (ICCPR) and the Code of Conduct for Law Enforcement Officials. The ICCPR provides a set of standards and provisions obligating states to address illegal arrests in a specified manner. Importantly, the Republic of Zimbabwe ratified ICCPR on May 13, 1991 and measures to curb unlawful arrest and detention are contained in the Constitution and the Criminal Procedure and Evidence Act [Chapter 9:11].

In the case of Minister of Home Affairs and Another vs. Bangajena 2000(1) ZLR $306(S)$, in which the owner of a car was wrongly arrested by a police officer who alleged that he was stealing the car, the supreme court highlighted that the deprivation of personal liberty is an odious interference and has always been regarded as serious injury. It was also held that the courts have properly taken 
the stance that deprivation of liberty through unlawful arrest and imprisonment is a very serious infraction of fundamental rights.

The idea of arresting-to-investigate, which was raised by some interviewees, is also highlighted by Feltoe (1997:261) who suggests that there has been a tendency for police to arrest first, and only then to investigate. The Criminal Procedure and Evidence Act specifies the grounds on which the arrest and detention of a suspect may occur, in which investigating is not mentioned as just cause. The Constitution of Zimbabwe (Section 50 (1) (a)) provides that every person arrested and detained must be informed at the time of arrest of the reason for the arrest. One of the interviewees, who was once formally accused, indicated that challenging an arrest would be asking for trouble from the police. Failure to abide by this constitutional provision, however, constitutes unlawful arrest.

'Dragnet arrest' is another form of unlawful arrest which emerges from this study. Dragnet arrests are unlawful arrests in which police officers indiscriminately arrest several suspects and detain them for screening (Matulich 2000). According to some of the interview respondents, dragnet arrests mainly take place during police operations when police officers indiscriminately arrest members of the public. Those arrested are taken to police stations where they are released if they cannot be linked to any offences. The presence of dragnet arrests, albeit on a smaller scale, is contradicted by Matulich's (2000) opinion that police should not indiscriminately arrest all the members of a group simply because one member of the group has committed an offence. The courts clearly outlawed dragnet arrests in the case of Feldman vs. Minister of Home Affairs 1992 (2) ZLR 304 in which five women were picked up and detained in relation to the allegation that they had stolen some cash. The court held that the police had reasonable grounds to believe that one of the five women had stolen the money, but they had no reason to suspect that the women had acted in concert. Feldman won the civil suit and was awarded damages.

\section{Arbitrary search and seizure}

Arbitrary search and seizure constitutes a grave violation of citizens' privacy and property rights. Mudzongo (2002) highlighted that searches, especially of individuals, their homes and property must only be carried out strictly and legitimately for law enforcement purposes. The Criminal Procedure and Evidence Act [Chapter 9:11] clearly spells out the circumstances under which the police can search and seize property, as well as the conduct of searches. 
Accordingly, any search that does not conform to the dictates of the law is an arbitrary search.

Arbitrary search and seizure as a form of abuse of power was also seen to be prevalent. Table 3 shows that while 38.6 percent of respondents indicated that arbitrary search and seizure is not common, the remaining respondents (61.4 percent) indicated that arbitrary search and seizure was either common (44.3 percent) or very common (17.1 percent).

Table 3 Respondents' perceptions of prevalence of arbitrary search and seizure

\begin{tabular}{ccc}
\hline Response & Frequency & Percent \\
Not common & 27 & 38.6 \\
Common & 31 & 44.3 \\
Very common & 12 & 17.1 \\
Total & 70 & 100.0 \\
\hline
\end{tabular}

Analysis of the prevalence of arbitrary search and seizure and area of residence (Table 4) shows that arbitrary search and seizure is more prevalent in Bindura District (63.9 percent) than in Mount Darwin District (51.7 percent). This claim is further supported by the fact that slightly below half (48.3 percent) of all the respondents from Mt. Darwin indicated that arbitrary search and seizure is not common, compared to 36.1 percent of respondents from Bindura. This may be explained by the fact that the crime rate is higher in Bindura, hence police conduct more searches in Bindura than in rural Mt. Darwin. Urban citizens interact more often with police officers and any wrong doing (such as arbitrary search and seizure) will be more visible.

Table 4 Prevalence of arbitrary search and seizure by area of residence (Respondents' perceptions)

\begin{tabular}{ccccc}
\hline \multirow{2}{*}{ Residence } & \multicolumn{2}{c}{ Prevalence of arbitrary search and seizure } & \multirow{2}{*}{ Total } \\
& Not common & Common & Very common & \\
\hline \multirow{2}{*}{ Bindura } & 13 & 18 & 5 & 36 \\
& $36.1 \%$ & $50.0 \%$ & $13.9 \%$ & $100.0 \%$ \\
\multirow{2}{*}{ Mt. Darwin } & 14 & 10 & 5 & 29 \\
& $48.3 \%$ & $34.5 \%$ & $17.2 \%$ & $100.0 \%$ \\
\multirow{2}{*}{ Other } & 0 & 3 & 2 & 5 \\
& $.0 \%$ & $60.0 \%$ & $40.0 \%$ & $100.0 \%$ \\
\hline \multirow{2}{*}{ Total } & 27 & 31 & 12 & $70^{*}$ \\
& $38.6 \%$ & $44.3 \%$ & $17.1 \%$ & $100.0 \%$ \\
\hline
\end{tabular}

* no data is available from three respondents 
Though a search warrant is a prerequisite for conducting a search, the Criminal Procedure and Evidence Act [Chapter 9:07] provides for wider powers of search without a warrant under Section 51 . This section is usually abused by police officers who capitalize on this statutory provision to engage in arbitrary searches. However, several successful cases have been filed against the police regarding arbitrary searches that lacked a search warrant.

\section{Malicious criminal prosecution}

Malicious criminal prosecution entails instituting a criminal action against an individual without reasonable cause, and having a criminal action terminated in favor of the accused (Okpaluba 2013). As an example, police officers may open criminal dockets based on frivolous facts, only for the cases to be thrown out by the courts. Although the name of the claim suggests that prosecutors are the primary defendants, police officers are also liable to be victims of malicious prosecution because they play a major role in the pre-trial phase, including the securing of arrest warrants (Goldstein 2006). This implies that police officers can also be held accountable for malicious criminal prosecution.

Malicious criminal prosecution is not a common form of police abuse of powers and functions. Table 5 shows that 67.2 percent of respondents indicated that malicious criminal prosecution is not common, while 32.9 percent indicated that malicious criminal prosecution is either common (29.9 percent) or very common (3 percent).

Table 5 Respondents' perceptions about prevalence of malicious criminal prosecution

\begin{tabular}{ccc}
\hline Response & Frequency & Percent \\
Not common & 45 & 67.2 \\
Common & 20 & 29.9 \\
Very common & 2 & 3.0 \\
Total & 67 & 100.0 \\
\hline
\end{tabular}

Analysis by area of residence (Table 6) shows that a larger proportion (68 percent) of respondents from Mt. Darwin district indicated that malicious criminal prosecution is not common, compared to 64.9 percent for Bindura district. This situation suggests that society is not conversant with this form of police abuse of power. 
Table 6 Prevalence of malicious criminal prosecution by area of residence (Respondents' perceptions)

\begin{tabular}{ccccc}
\hline \multirow{2}{*}{ Residence } & \multicolumn{2}{c}{ Prevalence of malicious criminal prosecution } & \multirow{2}{*}{ Total } \\
& Not common & Common & Very common & \\
\hline \multirow{2}{*}{ Bindura } & 24 & 12 & 1 & 37 \\
& $64.9 \%$ & $32.4 \%$ & $2.7 \%$ & $100.0 \%$ \\
Mt. Darwin & 17 & 7 & 1 & 25 \\
& $68.0 \%$ & $28.0 \%$ & $4.0 \%$ & $100.0 \%$ \\
Other & 4 & 1 & 0 & 5 \\
& $80.0 \%$ & $20.0 \%$ & $.0 \%$ & $100.0 \%$ \\
\hline \multirow{2}{*}{ Total } & 45 & 20 & 2 & $67 \%$ \\
& $67.2 \%$ & $29.9 \%$ & $3.0 \%$ & $100.0 \%$ \\
\hline
\end{tabular}

*no data is available from seven respondents

Most respondents who were interviewed did not mention this kind of abuse, except for two respondents with a legal background. Respondents may be unfamiliar with malicious criminal prosecution, but the present authors suggest that the increase in the number of acquittals in certain cases, especially those involving political factors, could be evidence of malicious criminal prosecution.

\section{Indiscriminate use of excessive force}

The constitutional mandate to preserve peace and maintain law and order sometimes necessitates the use of force. Harmon (2008: 1120) supports this notion when he remarks that police officers act with state authority, are often not permitted to retreat, and are trained in and expected to use force. Police officers may thus be caught in a dilemma when use of force conflicts with the ethics of duty and, specifically, with the dignity and personal autonomy of the public as subjects (Kleinig 1996). Despite the legal justification to use force, such force should be legal, proportionate to the threat, and necessary under the given circumstances.

The data in Table 7 reveal that most respondents indicated that police officers use excessive force during arrest and crowd dispersal. This is confirmed by 42.3 percent of respondents who reported that the police use of excessive force during arrest and crowd dispersal is common, while 21.1 percent were of the opinion that police use of excessive force is very common. Though 35.6 percent indicated that this form of abuse is not common, the statistics present a cause for concern. 
Table 7 Respondents' perceptions about the prevalence of excessive force during arrest and crowd dispersal

\begin{tabular}{ccc}
\hline Response & Frequency & Percent \\
Not common & 26 & 36.6 \\
Common & 30 & 42.3 \\
Very common & 15 & 21.1 \\
Total & 71 & 100.0 \\
\hline
\end{tabular}

Table 8 shows that most respondents (62.9 percent) from Bindura district indicated that police use of excessive force is either common (40 percent) or very common (22.9 percent), while 60 percent of respondents from Mt. Darwin indicated that use of excessive force is either common (53.3 percent) or very common (6.7 percent). Interestingly, a larger proportion (22.9 percent) in Bindura district view excessive use of force by the police as very common compared to only 6.7 percent for Mt. Darwin district. This can be explained by the fact that most of the public disorder situations take place in urban areas, mostly involving the dispersal of purported illegal political gatherings. Access to various media platforms enables society to access information about incidences of excessive use of force in other parts of the country and such access (especially private newspapers) is more pronounced in urban areas than in rural areas.

Table 8 Prevalence of use of excessive force during arrest and crowd dispersal by area of residence (Respondents' perceptions).

\begin{tabular}{ccccc}
\hline \multirow{2}{*}{ Residence } & $\begin{array}{c}\text { Prevalence of excessive force during arrest and crowd dispersal } \\
\text { Not common }\end{array}$ & Common & Tery common & Total \\
& 13 & 14 & 8 & 35 \\
\multirow{2}{*}{ Bindura } & $37.1 \%$ & $40.0 \%$ & $22.9 \%$ & $100.0 \%$ \\
& 12 & 16 & 2 & 30 \\
Mt. Darwin & $40.0 \%$ & $53.3 \%$ & $6.7 \%$ & $100.0 \%$ \\
& 1 & 0 & 5 & 6 \\
Other & $16.7 \%$ & $.0 \%$ & $83.3 \%$ & $100.0 \%$ \\
& 26 & 30 & 15 & $71 *$ \\
Total & $36.6 \%$ & $42.3 \%$ & $21.1 \%$ & $100.0 \%$ \\
\hline
\end{tabular}

* no data is available from two respondents

A number of interviewees indicated that the police use excessive force during arrest and crowd dispersal. One of the lay interviewees remarked that "In most cases, the force is just too much - water cannons, dogs, teargas - we do not 
need that". Other recent incidences of excessive use of force in the province could have affected respondents. The most recent incidence happened in nearby Shamva area where residents where brutalized by police officers who were looking for a suspect. One of the victims died and the incident received nationwide condemnation in both state and independent media (including The Sunday Mail and The Standard). Most of the respondents cited this incident during the interviews. The prevalence of excessive use of force was also noted in the studies conducted by Makwerere (2012) and The International Bar Association (2007).

However, some respondents justified the use of force by the police, especially during crowd control activities. One respondent noted that the peace that prevails in the country is testimony to the proper handling of disorderly situations by police.

One important factor that may be highlighted as regards the policing of public disorder is that the Z.R.P has a well-crafted public order management policy document. The major highlights in the document that were noted by the present researchers are the three principles concerning the use of force; namely, necessity, legality, and proportionality. The reported incidences of excessive use of force by the police suggest that police officers are failing to strike a balance between the three principles and are hence failing with implementation.

It should be noted, however, that at times police officers are at the receiving end of force although they treat demonstrators with leniency. Incidences occur when police officers get injured, raising dilemmas for police officers. As Harmon (2008) highlights, police officers are not permitted to retreat and are trained to use force. The public may not have a clear understanding of the principles governing the use of force in the same way as police officers, possibly due to a lack of information.

There is also documented evidence of the excessive use of force. Several civil suits have been filed against the police for excessive use of force, some of which are discussed in other parts of this study. One notable case is that of Musadzikwa vs. Minister of Home Affairs and Another 2000 (1) ZLR 405 (H) in which the court ruled that it was unreasonable for police officers to use automatic weapons in an urban environment. There is also documented evidence of serious injuries sustained by opposition leaders during their clashes with police (Human Rights NGO Forum, 2006).

Some respondents (36.6 percent) viewed the Z.R.P's way of responding to public disorder situations as ruthless, as depicted in Table 9. However, other statistics seem to suggest that the public still have confidence in how the police respond to situations of public disorder. The bulk of respondents indicated that the police's approach to public disorder situations was reasonable (26.8 percent), 
good (19.7 percent) or very good (16.9 percent). This shows that although incidences of excessive use of force are high, the public still trusts the Z.R.P to deal with public disorder situations.

Table 9 Respondents' perceptions about Z.R.P's responses to public disorder

\begin{tabular}{ccc}
\hline Response & Frequency & Percent \\
Ruthless & 26 & 36.6 \\
Reasonable & 19 & 26.8 \\
Good & 14 & 19.7 \\
Very good & 12 & 16.9 \\
Total & 71 & 100.0 \\
\hline
\end{tabular}

\section{Detention of accused persons beyond statutory limits}

Most respondents indicated that the excessive detention of accused persons is either common or very common. However, Table 10 also illustrates that 32.4 percent of respondents indicated that excessive detention of accused persons is not common while 36.6 percent and 31.0 percent indicated that excessive detention of accused persons is very common or common, respectively. In essence, the majority of respondents are inclined to believe that the excessive detention of accused persons by police is common.

Table 10 Respondents' perceptions about excessive detention of suspects

\begin{tabular}{ccc}
\hline Response & Frequency & Percent \\
Not common & 23 & 32.4 \\
Common & 22 & 31.0 \\
Very common & 26 & 36.6 \\
Total & 67 & 100.0 \\
\hline
\end{tabular}

The Criminal Procedure and Evidence Act [Chapter 9:07] provides that a person who is arrested for a criminal offence should be brought to court within forty-eight hours. This implies that if the detention of a suspect exceeds the stipulated forty-eight hours, the detention becomes unlawful. The forty-eight hour maximum detention period is also contained in Section 50 (2) of The Constitution of Zimbabwe. However, provision is made in both statutes for the extension of periods of detention. Members of the public who responded to the questionnaire may not have been aware of this provision. Detention itself 
involves such unpleasant conditions that even a twenty-four hour period may be considered by a layman as excessive. One of the reasons for the excessive detention of suspects is failure to finalize investigations before taking the suspect to court, and in some cases such investigation requires the presence of the suspect. However, excessive detention can also be used to punish criminals, though such action is illegal.

There is documented evidence of excessive detention, some of which cases have culminated in civil suits against the police. One respondent stated that police sometimes detain suspects for an overly long period, and then issue warrants for such further detention to cover up their misdeeds. In the case of Moll vs. Commissioner of Police and Others 1983 (1) ZLR 238 (H), the plaintiff was arrested and charged for contravening a section of the Emergency Powers Regulation after allegedly making derogatory remarks about the prime minister. He was detained for over two months, despite the fact that an order to release him had been issued by a magistrate. The detention was ruled to be unlawful by the court. Police officers should thus take the accused person to court at the earliest possible opportunity and not wait for forty-eight hours when they can complete investigations in six hours.

\section{Denial of Medical treatment and legal representation}

The Constitution of Zimbabwe, under Section 50, provides for the rights of arrested and detainees. Arrested and detained persons must be permitted to consult with a legal practitioner and a medical practitioner of their choice and, more importantly, they must be promptly informed of this right.

Table 11 shows that most respondents indicated that detainees are accorded access to medical treatment. This claim is substantiated by the 52.2 percent of respondents who disagreed with the fact that detainees are denied access to medical treatment. However, $40.6 \%$ of respondents agreed that detainees are denied access to medical treatment; a proportion large enough to cause concern. Respondents have the perception that police always ill-treat detainees. This fact was observed by the researcher through interaction with members of the public. However, these responses may have been influenced more by hearsay than tangible evidence. A greater proportion of respondents were of the opinion that accused persons are given access to legal representation. While 66.7 percent of respondents are inclined to disagree with the fact that accused persons are denied access to legal representation, 33.3 percent are inclined to agree. However, despite accessibility to legal representation, half of all respondents 
agree $(50 \%)$, or strongly agree (11.8 percent) that detainees are delayed access to legal representation.

Table 11 Respondents' perceptions about medical treatment and legal representation of detainees

\begin{tabular}{|c|c|c|c|c|c|}
\hline Question & $\begin{array}{l}\text { Strongly } \\
\text { disagree }\end{array}$ & Disagree & Agree & $\begin{array}{c}\text { Strongly } \\
\text { agree }\end{array}$ & Total \\
\hline $\begin{array}{l}\text { Accused persons are denied access to } \\
\text { medical treatment }\end{array}$ & $2.9 \%$ & $52.2 \%$ & $40.6 \%$ & $4.3 \%$ & $100 \%$ \\
\hline $\begin{array}{c}\text { Accused persons are denied access to } \\
\text { legal representation }\end{array}$ & $1.4 \%$ & $65.3 \%$ & $30.4 \%$ & $2.9 \%$ & $100 \%$ \\
\hline $\begin{array}{l}\text { Detained persons have delayed access } \\
\text { to legal representation }\end{array}$ & $2.9 \%$ & $35.3 \%$ & $50 \%$ & $11.8 \%$ & $100 \%$ \\
\hline
\end{tabular}

While the statistics about detainees' access to medical treatment and access to legal representation appear to support the actions of the Z.R.P, other statistics indicate cause for concern. One of the accused persons who was interviewed claimed that he had been denied access to medical treatment after being assaulted (hit on the soles of his feet) by the police during investigations. He claimed that he had been unable to walk properly and was only taken to court when the pain subsided.

Concerning the issue of accessibility to legal representation, one of the respondents who had a legal background remarked that "it would be suicidal for police to outright deny accused persons access to legal counsel". Access to a legal representative is a constitutional right which should be accorded to detainees. In the case of Minister of Home Affairs vs. Dabengwa 1982 (1) ZLR $236 \mathrm{~S}$, the accused was detained under Emergency Powers Regulation and the local authority issued regulations prohibiting detainees from communicating with or receiving communication from their lawyers. The court permitted the detainee access to his lawyer. If such a right could be accorded under a state of emergency, then incidences of the denial of legal representation should not occur under the prevailing peaceful environment. Delayed access to legal representation is also a violation of an accused person's rights. Some respondents highlighted that most official warnings and cautions are recorded in the absence of the accused person's lawyer. The International Bar Association (2007) also noted that there is often obstruction of legal representatives by police. Such obstruction culminates in delayed access to clients by lawyers. In the case of $S$ vs. Slatter 1983 ZLR 144 , it was held that proceedings are subverted when lawyers seeking access to clients are denied access. 


\section{Abuse of powers for investigating crimes}

Abuse of the power to investigate entails the use of illegal means, such as assaulting suspects, use of torture, and other forms of pressure as a way of inducing suspects to confess to committing a crime. Most respondents were of the opinion that police use torture and illegal methods of obtaining confessions and evidence. The study (as revealed in Table 12) illustrates that 52.4 percent of respondents believed that police officers use torture and illegal methods to obtain confessions and evidence, while 29.2 percent did not.

Table 12 Respondents' perceptions about use of torture and illegal methods to obtain confessions

\begin{tabular}{ccc}
\hline Response & Frequency & Percent \\
Strongly disagree & 9 & 12.50 \\
Disagree & 12 & 16.70 \\
Neutral & 14 & 19.40 \\
Agree & 16 & 22.20 \\
Strongly agree & 21 & 29.20 \\
Total & 72 & 100.0 \\
\hline
\end{tabular}

The nature of the torture that was highlighted during interviews included the assaulting of those accused using batons and various forms of threats. It should be noted that the definition of torture is wide, and what may appear as minimum force in the eyes of police officers may amount to torture. Torture is a serious violation of a person's dignity and is outlawed internationally through instruments such as the UDHR, ICCPR and CAT. Article 1 of the CAT defines torture as follows: "Any act by which severe pain or suffering whether physical or mental, is intentionally inflicted on a person for such purposes as obtaining from him or a third person information or a confession, punishing him for an act he or a third person has committed or is suspected to have committed, or intimidating or coercing him or a third person, or for any reason based on discrimination of any kind, when such pain or suffering is inflicted by or at the instigation of a public official or other person acting on an official capacity."

Several civil cases have been filed against the police for use of torture during investigations. In the case of State v Slatter 1983 ZLR 144, the accused were charged with aiding and abetting sabotage of an air force base. No evidence was presented to implicate the accused apart from their own statements which were procured through threats and torture. Rendering their confessions inadmissible, the court held that maltreatment during questioning makes statements 
inadmissible. The court also held that magistrates are obliged to question accused persons to ascertain whether confessions have been made illegally. Similarly, the courts ruled in favor of the plaintiffs in the following cases in which civil suits were filed concerning the use of torture and assault by police;

- Karimazondo and Another v Minister of Home Affairs and Another 2001 (2) ZLR $363(\mathrm{H})$

- Mugwagwa v Minister of home Affairs and Commissioner of Police HH183-2004

- State v Reza HH- 02- 2004

- Mukumba V Minister of Home Affairs and Another HH-84-2009

- Nyandoro v Minister of Home Affairs and Another HH- 196- 2010

- Muskwe V Minister of Home Affairs and Others HH-83-2013.

The above cases may indicate an ongoing trend to abuse of power through torture and assault by police officers. However, some people are of the view that police officers should apply a bit of pressure on those accused so that meaningful investigations take place. Table 13 shows that 34.7 percent of respondents consider assaulting suspects to be justified if it leads to the recovery of stolen property. Though more respondents would not justify torture, the former figure is large enough to cause concern.

Table 13 Opinion of respondents about whether assaulting suspects is justified if it leads to the recovery of stolen property

\begin{tabular}{ccc}
\hline Response & Frequency & Percent \\
Yes & 25 & 34.7 \\
No & 47 & 65.3 \\
Total & 72 & 100.0 \\
\hline
\end{tabular}

Some authors also justify the use of some illegal means to solve criminal cases. Taylor (1995) asserts that criminals are often sophisticated, and evidence against them is hard to come by except through their own confessions. Under such situations, the only way to deal with criminals is through the use of unorthodox means. Section 258 of the Criminal Procedure and Evidence Act [Chapter 9:07] provides that evidence discovered by means of forced confession is inadmissible in the court of law. One respondent spoke of situations in which there is glaring evidence that links the accused to a theft, but the former still deny their involvement. The respondent argued that it is in such situations that the accused should be pressured to reveal the whereabouts of the stolen property. However, any illegal activity that occurs during investigations should 
not be condoned, and police officers should execute their power to investigate in accordance with the law.

\section{Partisan politics in policing}

In a democratic country, the police force should be a politically neutral arm of the state that applies the law equally to all persons. Partisan policing occurs when police officers show bias towards a political party during their policing activities. Most respondents indicated that partisan policing is either common or very common. Table 14 shows that almost half ( 49.3 percent) of all respondents indicated that partisan policing is not common. The remaining respondents (50.7 percent) indicated that partisan policing is either common or very common.

Table 14 Respondents' perceptions about the prevalence of partisan policing

\begin{tabular}{ccc}
\hline Response & Frequency & Percent \\
Not common & 34 & 49.3 \\
Common & 21 & 30.4 \\
Very common & 14 & 20.3 \\
Total & 69 & 100.0 \\
\hline
\end{tabular}

The comparative analysis in Table 15 shows that most of the respondents from Bindura district (52.8 percent) view partisan policing as common (27.8 percent) or very common (25.0 percent) while 40.7 percent of respondents from Mt. Darwin view partisan policing as common or very common. This implies that most respondents from Mt. Darwin district (59.3 percent) consider partisan policing not to be common. There are two dominant political parties in the province, namely the Zimbabwe African National Union Patriotic Front (ZANU PF) and the Movement for Democratic Change (MDC). Though ZANU PF is the dominant party, especially in rural areas, the opposition MDC has a number of supporters in Bindura town. This could have contributed to the high number of respondents who indicated that partisan policing is very common in Bindura District. The International Bar Association (2007) has indicated that police in Zimbabwe repeatedly characterize government opponents and critics and their lawyers as agents of the West or enemies of the State, and routinely violate the rights of those persons during political operations. Incidences of partisan policing have also been reported in other urban areas around the country. 
Table 15 Prevalence of partisan policing by area of residence (Respondents' opinions)

\begin{tabular}{ccccc}
\hline \multirow{2}{*}{ Residence } & \multicolumn{3}{c}{ Prevalence of partisan policing } & \multirow{2}{*}{ Total } \\
& Not common & Common & Very common & \\
\hline \multirow{2}{*}{ Bindura } & 17 & 10 & 9 & 36 \\
& $47.2 \%$ & $27.8 \%$ & $25.0 \%$ & $100.0 \%$ \\
Mt. Darwin & 16 & 10 & 1 & 27 \\
& $59.3 \%$ & $37.0 \%$ & $3.7 \%$ & $100.0 \%$ \\
Other & 1 & 1 & 4 & 6 \\
& $16.7 \%$ & $16.7 \%$ & $66.7 \%$ & $100.0 \%$ \\
\hline \multirow{2}{*}{ Total } & 34 & 21 & 14 & 69 \\
& $49.3 \%$ & $30.4 \%$ & $20.3 \%$ & $100.0 \%$ \\
\hline
\end{tabular}

*4 did not respond

Commenting on the issue of partisan policing on a television programe, the police spokesperson Senior Assistant Commissioner Charity Charamba maintained that "We support the policies of the government in power; if MDC comes to power we will support them. If we do not follow government policies, we will be labelled rebels" (Zimbabwe Television 2013). It is without doubt that police officers cannot bite the hand that feeds them, hence they have to show allegiance to political authorities.

\section{CONCLUSION}

The results of the analysis and discussions indicate that police officers abuse their powers in their day-to-day interaction with the public. Unlawful arrest is viewed as the most dominant form of police abuse of power and occurs in the forms of: the arrest of individuals without probable cause; arrests for the purpose of investigations; not informing suspects of the reasons for their arrest, and; dragnet arrest. Other common forms of police abuse of powers and functions as highlighted by respondents include arbitrary search and seizure and indiscriminate use of excessive force. Interestingly though, the three forms of abuse are considered to be more common in urban areas than in rural areas. Unlawful methods of investigation, such as use of torture to obtain confessions, are also seen as being prevalent, though a number of respondents justified the use of torture which leads to the recovery of stolen property. Although most respondents were of the view that accused persons are allowed access to legal representation, most of them still believe that such access is often delayed. Though the presence of partisan policing and malicious criminal prosecutions 
were noted by some respondents, they are not seen as being as prevalent as other forms of abuse.

Whilst there may be internal mechanisms for dealing with incidents of police abuse of power, the findings of this study suggest that such mechanisms could either be inadequate or ineffective. With the government's drive to promote the greater accountability of public institutions, there is need for a more professional- and human-rights-conscious police force. Whilst filing civil suits against the police presents an opportunity for victims of abuse to seek recourse, the process is costly and only a few can afford it. Promoting intense human rights education for recruits during their initial stages of training, as well as continuous refresher courses would promote human rights awareness among police officers. In the absence of an independent body for investigating police misconduct in Zimbabwe, there is need for a transparent internal police complaints mechanism, whereby victims could be informed of the outcome of investigations of incidents of police abuse of power.

The present authors also wish to point out two major limitations of this study. The first limitation is that the data for the sample stemmed from the residents of two districts, thus it is not representative of the whole country. Furthermore, the sample is not representative at the district level; nonetheless, it may still provide a general picture of the opinions of inhabitants and focus attention on problems with the police abuse of power.

\section{REFERENCES}

Anti-Corruption Trust of Southern Africa. 2013. Zimbabwe: When Security Agents are abused by politicians for personal benefit: Perception on the conduct of the Z.R.P against Zimbabwean Civil Society Organizations and Human Rights defenders [Online]. Available from:www.swradioafrica.com/ Documents/Zimbabwe When the security forces are abused by politicians.pdf [Accessed: 22/02/2013]

Feltoe, G. (2012), A guide to the Zimbabwean Law of Delict [Online]. Available from: ir.uz.ac.zw/jspui/bitstreem/10646/663/1/Delict Guide 25 Jan 2012.pdf. [Accessed on: 16/06/2013]

Feltoe, G. (1997), "Report on the Internal Security Forces in Zimbabwe", Third World Legal Studies Vol. 14, Article 3 [Online]. Available from http://scholar. valpo.edu/twls/vol14/iss1/3. [Accessed on 19/03/2013]

Goldstein, J. P. (2006), "From the Exclusionary Rule to a Constitutional Tort for Malicious Prosecutions" Columbia Law Review Vol. 106, No 3, pp. 643-678 
Harmon, R. A. (2008), "When is police violence justified?", Northwestern University Law Review Vol. 102, No 3, pp. 1119-1188

Human Rights NGO. (2006), Who guards the guards? Violations by the Zimbabwe Republic Police, 200 to 2006. Harare: Human Rights NGO Forum Human Rights Watch. (2008), Our Hands are tied: Erosion of the rule of law in Zimbabwe [Online]. Available from: www.hrw.org/sites/default/files/reports/ Zimbabwe1108.pdf [Accessed: 25/02/2013]

International Bar Association. (2007). Partisan Policing: An Obstacle to human rights and democracy in Zimbabwe. USA: International Bar Association

Kleining, J. (2008). Ethics and Criminal Justice: An Introduction. United Kingdom, University Press

Makwerere, D. - C. G. Tafadzwa - M. Collen (2012), "Human Rights and Policing. A Case Study of Zimbabwe", International Journal of Humanities and Social Sciences Vol. 2, No 17, pp. 129-138.

Matulich, A. (2000), Policing Tortuous Policing. Harare, Legal Resources Foundation

Mudzongo, G. (2002), Promoting police observance on Human Rights: A model of incorporating Human Rights Education in Police Training. University of Lund

Okpaluba, C. (2013). Reasonable and Probable cause in the law of malicious prosecution: A review of South African and Commonwealth decisions. 2013 (16) 1 PER/ PELJ: twenty-four 1-279

Republic of Zimbabwe (2006), Criminal Law (Codification and Reform) Act [Chapter 9:23]. Government Printers

Republic of Zimbabwe (2013), The Constitution of Zimbabwe. Amendment (No 20). Government Printers

Republic of Zimbabwe (1980), The Criminal Procedure and Evidence Act (Chapter 9:07). Harare: Government Printers

Taylor, A (1995), Evidence. London, Cavendish Publishing Company

Zimbabwe Television (2013), Interview with the Zimbabwe Republic Police Spokesperson on the Programme, "Melting Pot" on 15 August 2013 
